\title{
Innovation as Spiritual Exercise: Montaigne and Pascal
}

\author{
Pierre Force
}

The rediscovery of the rhetorical tradition in the past thirty years has transformed the study of early modern authors like Montaigne and Pascal. ${ }^{1}$ The categories of traditional literary history, like originality, influence, predecessors, and followers, are now seen as inadequate when it comes to explaining how Montaigne and Pascal thought of themselves as authors and how they understood the process of intellectual discovery and literary production. ${ }^{2}$ In the same perspective looking for originality (in the modern sense of the term) in early modern authors is now seen as a misguided enterprise. In the rhetorical culture of early modern Europe every author writes in a given tradition, and every new book is to be understood within the tradition or traditions to which it belongs. Pascal borrows heavily from Montaigne, sometimes verbatim, sometimes not. ${ }^{3}$ Montaigne draws from Seneca, Plutarch, Cicero, and many others.

Having realized this, the modern reader is tempted to conclude that authors like Montaigne and Pascal, absorbed as they are in their conversation with the great authors from the past, are not interested in saying anything new. Yet the opposite is true. Pascal famously preempts a possible objection to his Pensées by saying, "Let no one say that I have said nothing new; the arrangement of the

Thanks to Kathy Eden for comments and suggestions.

${ }^{1}$ Successful examples of a rhetorical approach to early modern intellectual history include Marc Fumaroli, L'Âge de l'éloquence (Paris, 1994 [Geneva, 1980]); Quentin Skinner, Reason and Rhetoric in the Philosophy of Hobbes (Cambridge, 1996); and Kathy Eden, Friends Hold All Things in Common. Tradition, Intellectual Property, and the Adages of Erasmus (New Haven, Conn., 2001).

${ }^{2}$ A good example of the traditional approach is Henri Gouhier's excellent book on the relationship between Descartes and Augustine (which will be discussed later in this article): Cartésianisme et augustinisme au XVIIe siècle (Paris, 1978). Gouhier discusses the Augustinian "sources" of Descartes's philosophy and Descartes's "originality" with respect to those sources.

${ }^{3}$ See Bernard Croquette, Pascal et Montaigne: Etude des réminiscences de Montaigne dans l'œuvre de Pascal (Geneva, 1974). 
material is new" (696). ${ }^{4}$ As to Montaigne, his contempt for novelty in general is well known. However, he praises traveling because "the mind is continually exercised in observing new and unknown things." In addition, in his dedication to Madame d'Estissac at the beginning of the chapter "Of the affection of fathers for their children" he suggests that the value of his book may well reside entirely in the fact that its subject matter is new: "Madame, if strangeness and novelty, which customarily give value to things, do not save me, I shall never get out of this stupid enterprise with honor; but it is so fantastic and appears so remote from common usage that that may enable it to pass."

This passage seems paradoxical to the modern reader but for reasons that Madame d'Estissac would not understand. In a self-deprecating move Montaigne asserts that nothing could recommend his book to a reader. Its only redeeming value is that it does not resemble anything that has been published before. Of course to a modern reader this would be the most important, perhaps even the only criterion, of literary worth. For Montaigne himself, if we note the irony of the passage, novelty is not in itself a criterion of literary value, because novelty for its own sake, especially in matters of style, is worthless. At the same time Montaigne is clearly saying that his literary project (writing a book about himself) is valuable because it is unlike anything that has been tried before.

On the one hand it is clear that for both Montaigne and Pascal "saying something new" is a major criterion of literary and philosophical worth. On the other hand "saying something new" is not a synonym for "being original" (in the modern sense of the term). I would therefore like to come to Montaigne and Pascal with the following questions: How do you say something new? How can you tell that someone is saying something new?

Pascal discusses these questions extensively in a digression near the end of a small unfinished treatise entitled Mathematical Mind. The purpose of the treatise is to enunciate the rules that govern the art of true demonstrations. After spelling out those rules he replies to three possible objections, the first being that "there is nothing new about this method."7 Pascal's reply to the first objection is a complex one. He begins by acknowledging that the rules he has just enunciated or at least something resembling those rules can indeed be found in some well-known treatises of logic. He adds that those who read quickly and superficially will not see the difference between Pascal's treatise and the works of logic that are already available. He claims, however, that those who read

\footnotetext{
${ }^{4}$ Pascal, Pensées, tr. A. J. Krailsheimer (London, 1966). The number after each quote from the Pensées is the fragment number in Krailsheimer's translation, which follows the numbering of the Lafuma edition (Paris, 1963).

${ }^{5}$ Montaigne, Essays, tr. by Donald M. Frame (Stanford, Calif., 1958), III, 9, p. 744.

${ }^{6}$ Essays, II, 8, p. 278.

${ }^{7}$ De l'Esprit géométrique, in Les Provinciales, Pensées et opuscules, ed. Gérard Ferreyrolles and Philippe Sellier (Paris, 2004), 139, translation is mine.
} 
very carefully will see the difference: "But if they grasp the spirit of these rules, and if the rules have made a such a mark on them that they have taken root and thrived, they will realize what a difference there is between what is said here, and what some logicians may have written that is coincidentally similar in some parts of their works." 8

For Pascal, reading carefully means paying attention to several things. First, it is necessary to consider "the places and circumstances" of the statements you are comparing. ${ }^{9}$ In other words who said it, where, and when? Second, you must find out if the person who utters these words is capable of relating them to the rest of the book they come from: "Does anyone really believe that two persons who have read and memorized the same book know it equally, assuming that one understands it in such a way that he knows all its principles, the strength of its consequences, how to respond to the objections that may be made against it, and the whole economy of the work; while for the other, those would be like dead words...." 10

Finally, Pascal presents his reader with a comparison between the famous principle, I think, therefore I am, as stated in Descartes and the same principle as enunciated by Augustine twelve hundred years before. Pascal requires only two things of the reader in making the comparison: the reader must be "equitable," and the comparison must be between "the spirit of Descartes" and the "spirit of saint Augustine." 11

At first sight these recommendations may seem a bit vague or banal. However, behind the non-technical language lies a very specific set of prescriptions. Paying attention to "places and circumstances" means considering what the rhetorical tradition calls decorum. Cicero defines the eloquent speaker as the one who can adapt his speech (the Latin term is accommodare) to every possible circumstance. As Kathy Eden shows in Hermeneutics and the Rhetorical Tradition, decorum is not only a principle of rhetorical composition; it is a hermeneutic principle as well. In matters of literary exegesis (enarratio poetarum) considering decorum means interpreting a text with regard to its historical context. ${ }^{12}$ According to Quintilian, the interpretation of literature is based on two principles: decorum and oeconomia, a Greek word for which he says there is no Latin equivalent. Decorum is a principle that operates within the sphere of elocutio: interpreting a text on the basis of decorum means looking at the words and expressions an author uses and showing that these words and expressions were chosen to fit a particular audience at a particular time.

${ }^{8}$ De l'Esprit géométrique, 140.

${ }^{9}$ De l'Esprit géométrique, 140.

${ }^{10}$ Ibid.

${ }^{11}$ De l'Esprit géométrique, 141. Cf. Henri Gouhier, Cartésianisme et augustinisme au XVIIe siècle, and Emmanuel Bermon, Le Cogito dans la pensée de saint Augustin (Paris, 2001).

${ }^{12}$ Kathy Eden, Hermeneutics and the Rhetorical Tradition (New Haven, Conn., 1997), 26. 
Oeconomia operates within the sphere of dispositio. Eden points out that whereas dispositio refers to a straightforward arrangement of the material, "oeconomia follows a more indirect, artificial organization, one altered specifically to accommodate the circumstances of the case, with the special end of arousing the audience's emotions." ${ }^{13}$ Quintilian defines oeconomica dispositio as the art of rearranging the traditional parts of a speech (either by changing the order or by skipping some parts) in order to obtain the desired effect on the audience. Sometimes, Quintilian adds, the most effective order consists in starting, like Homer (more Homerico), at the middle, or the end. This of course can be done only in view of the specific circumstances of the case, and, indeed, in order to practice this type of dispositio effectively, the orator must have every detail of the case in mind, and he must know exactly where he wants to take his interlocutor. As Eden puts it, "this kind of composition takes as its starting point a decisive relationship between the whole and the parts. Indeed, it presupposes the whole in composing the parts. ${ }^{.14}$ Like decorum, oeconomia is both a principle of rhetorical composition and a hermeneutic principle. Reading a text economically means looking at the relationship between the parts and the whole. More specifically, it means understanding every part of the text in view of the meaning of the whole. This is the principle Pascal refers to when he says that the reader must understand "the whole economy of the work." A good reader must be able to spell out the connections between every statement in the book and the first principles that support it. In order to do this successfully one must have a clear sense of what the book as a whole is saying. The meaning of the whole guides the interpretation of the parts.

Finally, in the rhetorical tradition the interpretation of a text (interpretatio scripti) is governed by a principle that is even more general than decorum and oeconomia, the principle of equity, which consists in invoking the author's intent (voluntas) when the text (scriptum) proves too difficult to understand. ${ }^{15}$ In particular, judges are equitable when they manage to accommodate the generality of the law to the particular circumstances of a case. In so doing, they rectify the law that is defective because of its generality, and they clarify the intent of the lawgiver. Equity is therefore the cardinal virtue of hermeneutics. ${ }^{16}$ This is why Pascal asks for an "equitable" reader in order to decide whether Descartes said something new when he put forward his famous principle, $I$ think, therefore I am. An equitable reader is someone who pays attention to decorum and oeconomia when interpreting a passage. In other words an equi-

${ }^{13}$ Hermeneutics and the Rhetorical Tradition, 28.

${ }^{14}$ Hermeneutics and the Rhetorical Tradition, 29.

${ }^{15}$ See Hermeneutics and the Rhetorical Tradition, 12-16.

${ }^{16}$ See H.-G. Gadamer, Truth and Method, tr. Joel Weinsheimer and Donald G. Marshall (New York, 1989), esp. 324-41. 
table reader must have a clear grasp of an author's intent as it appears through the entire book in order to interpret what is written in a particular passage. This is what Pascal refers to as "the spirit of Descartes" and "the spirit of saint Augustine."

According to Pascal, no one has explained these issues more clearly than Montaigne, whom he calls "the incomparable author of L'Art de conférer." 17 Like all of Montaigne's essays, "Of the art of discussion" is somewhat enigmatic. In particular, it is not easy to understand what conférer really means. But Pascal's paraphrase of Montaigne's text in Mathematical Mind may be a good indication of what l'art de conférer is about. This approach has allowed Laurent Thirouin to show the richness and complexity of the word conférer in Montaigne. ${ }^{18}$ First, conférer means to debate, but this is something other than simple conversation. The conférences Montaigne refers to in the essay are always adversarial; it is always about the confrontation of two opposite viewpoints. Second (and this works also in English), conférer means to assign, to confer a value or a title to something or someone: a significant part of the essay discusses the relationship between the intrinsic merit of people and the dignities and honors they receive. In that sense conférer means both literally and metaphorically putting a price on something or someone. Third, conférer means to compare and specifically to assess the relationship between two texts in order to determine their true worth. The value of a work always emerges in comparison with other works. In the final analysis Thirouin shows that the issue at the core of De l'Art de conférer is how do you assess the value of a person or a text? What I would like to show now is that for both Pascal and Montaigne value and innovativeness are very closely related. Asking whether a person or a text is saying something new is another way of asking what a person or a text is worth.

The passage from Montaigne that Pascal paraphrases begins with the following statement: “... in arguments and discussions not all the remarks that seem good to us should be accepted immediately. Most men are rich with borrowed capacity" (d'une suffisance estrangere).${ }^{19}$ The crucial distinction here is between what is alien (estrangere) and what is one's own. As Montaigne puts it a bit further in the essay, in order to assess the true worth of an author, "we must know what is his and what is not." ${ }^{20}$ How does one perform such a test? First, Montaigne says knowledge and memory are irrelevant because they say very little about the persons themselves (or the text themselves). They do not

${ }^{17}$ De l'Esprit géométrique, 140.

${ }^{18}$ Laurent Thirouin, "Pascal et 'l'art de conférer,' " Cahiers de l'Association internationale des études françaises, 40 (1988), 199-218.

${ }^{19}$ Essays, III, 8, p. 714.

${ }^{20}$ Essays, III, 8, p. 718. 
reveal anything, Montaigne argues, about "the strength and beauty" of the interlocutor's (or the author's) soul. ${ }^{21}$ What is "the strength and beauty" of a soul? In a passage from Book I of the Essays Montaigne complains about the extreme inadequacy of his memory, but he then argues that there is strength in that weakness. Because he is unable to remember anything, Montaigne has had to exercise his mind and his judgment much more than others had to:

I have some consolation. First, because it is an evil that has shown me the way to correct a worse evil which would easily have developed in me - to wit, ambition; for lack of memory is intolerable in anyone who is involved in public negotiations. Because, as several similar examples of nature's processes demonstrate, nature has tended to strengthen other faculties in me in proportion as my memory has grown weaker; and I might easily rest my mind and judgment and let them grow languid following on others' traces, as everyone does, without exercising their own strength, if other men's discoveries and opinions were always present to me by virtue of my memory. My speech is the briefer for it. For the magazine of memory is apt to be better furnished with matter than that of invention. ${ }^{22}$

In this passage Montaigne distinguishes between memory (mémoire), mind (esprit), and judgment (jugement). These are the three faculties of the soul that, according to the rhetorical tradition, make eloquence possible and need to be developed through exercise: memoria (the ability to remember one's speech as well as the opponent's arguments), ingenium (natural intelligence and imagination), and judicium (good sense and good taste).

In Montaigne's interpretation of these categories memory says little about the natural and intrinsic qualities of a soul because its purpose is to retain things that are alien to the self. Montaigne adds that having a bad memory has forced him to be self-reliant and to cultivate what is truly his own, i.e., his mind and judgment. From this passage one can infer that when he mentions "the strength and beauty of a soul" in opposition to its ability to memorize, he is referring to what he sees as the intrinsic qualities of a soul: esprit and jugement. For Montaigne "a strong and beautiful soul" is one that has both mind and judgment and therefore one that is capable of saying things that are truly its own. Conversely, finding something in an author or an interlocutor that is genuinely new and un-borrowed is the sign that the author or the interlocutor is intellectually self-reliant and has a strong and beautiful soul. This does not mean that the subject matter and everything else that falls under the rhetorical category of

${ }^{21}$ Essays, III, 8, p. 718.

${ }^{22}$ Essays, I, 9, p. 22. 
inventio must be entirely new. Innovation with respect to the subject matter is an important way of saying something new (as we have seen before, Montaigne does claim that presenting himself as the subject matter of his book is the principal literary innovation in the Essais). However, this is not the only possible way. One must also consider the "choice, arrangement, embellishment, and style" (chois, disposition, ornement et langage) that the author has contributed. "23 "Choice" has to do with inventio. Even if the subject matter is not new, an author may innovate by making a choice, a selection in a series of ideas that are traditionally invoked together, and this choice may be remarkably appropriate to what the author is trying to say. An author may also innovate in the sphere of dispositio by presenting known ideas and materials in an order that has never been seen before ("arrangement"). Finally, one may innovate in the area of elocutio ("embellishment, and style") by using a style that breaks with earlier practice.

I should add that Montaigne generally manifests a good deal of contempt for stylistic innovation. For instance, in this passage he compares it to borrowed and extravagant clothes that hide the true worth of a text:

The eloquence that diverts us to itself harms its content.

As in dress it is pettiness to seek attention by some peculiar and unusual fashion, so in language the search for novel phrases and littleknown words comes from a childish and pedantic ambition. Would that I might use only those that are used in the markets of Paris! Aristophanes the grammarian did not know what he was talking about when he criticized Epicurus for the simplicity of his words and the aim of his rhetorical art, which was simply lucidity of speech. The imitation of speech, because of its facility, may be quickly picked up by a whole people; the imitation of judgment and invention does not come so fast. Most readers, because they have found a similar robe, think very wrongly that they have hold of a similar body. Strength and sinews are not to be borrowed; the attire and the cloak may be borrowed. ${ }^{24}$

As we have seen in previous examples, the crucial distinction here (metaphorically represented by the body and the clothes) is between what is alien and what is an author's own. Montaigne seems to say (and this is of course counter-intuitive for a modern reader) that style is the least personal quality in an author because it can be so easily imitated. "The imitation of judgment and invention" is much more difficult. It is very difficult to imitate someone's judgment because, as a personal quality, good judgment is not transferable. Simi-

${ }^{23}$ Essays, III, 8, p. 718.

${ }^{24}$ Essays, I, 26, p. 127. 
larly, it is very difficult to imitate someone's invention (or rather someone's capacity for invention) because it proceeds from the mind (esprit), a natural and personal quality. One may wonder why Montaigne is so adamant against stylistic innovation, since he is now acknowledged to be a stylistic innovator himself. Here, Montaigne speaks about stylistic innovation for its own sake in the manner of the sophists. For Montaigne in the Essais the use of new language should always be governed by decorum: anything new about the language must be consistent with the subject matter.

It should be emphasized here that for Montaigne although the "new" is a fundamental criterion of literary and philosophical worth, "saying something new" is never presented as being good for its own sake. What Montaigne seeks is not the "new" itself but rather what the "new" points to, i.e., a "strong and beautiful soul" in an interlocutor or an author. For Montaigne, reading and conversation are spiritual exercises that do for the soul what physical exercise does for the body: the stronger the training partner is, the more beneficial the exercise is likely to be. ${ }^{25}$ This comes across very clearly in the chapter on the education of children. Interpreters of this chapter usually insist on Montaigne's description of a process of appropriation: the young student who reads and fully understands Plato owns Plato's ideas as much as Plato himself did: "It is no more according to Plato than according to me, since he and I understand and see it in the same way." ${ }^{26}$ However, the focus is not as much on intellectual ownership as it is on intellectual activity as a way of exercising both mind and judgment. A soul becomes "strong and beautiful" through spiritual exercise, just as a dancer excels through persistent practice: "I wish Paluel or Pompey, those fine dancers of my time, could teach us capers just by performing them before us and without moving us from our seats, as those people who want to train our understanding without setting it in motion." ${ }^{27}$

For Montaigne, appropriating Plato's ideas is not aimed at claiming ownership of those ideas. It is aimed at exercising one's soul in order to match the "strength and beauty" of Plato's soul. A similar comment can be made about the passage I quoted at the beginning of this article on Montaigne's appreciation of the "new" in the practice of traveling: "the mind is continually exercised in observing new and unknown things." ${ }^{28}$ Observing "new and unknown" things is not an end in itself; it is a practice aimed at making the mind stronger.

Pascal follows all these principles in Mathematical Mind. He argues for the innovativeness of his treatise on the grounds of inventio, dispositio, and decorum. He acknowledges that some of the rules he enunciates can be found

\footnotetext{
${ }^{25}$ See Pierre Hadot, Philosophy as a Way of Life, ed. Arnold I. Davidson (Oxford, 1995).

${ }^{26}$ Essays, I, 26, p. 111.

${ }^{27}$ Essays, I, 26, p. 112.

${ }^{28}$ Essays, III, 9, p. 744.
} 
in some well-known treatises of logic. Yet he says these precious and essential rules are mixed up with many others that are either false or useless. As far as inventio is concerned, the innovation consists in having chosen the rules that are relevant and leaving out the irrelevant ones. He also acknowledges that the rules he puts forward are familiar to mathematicians. Yet mathematicians are few and far between. The treatise is not destined for them (because they already understand). It is useful, however, to everybody else, who will genuinely learn something by reading the treatise. That is the innovativeness as far as decorum is concerned. The treatise is new for its intended audience: non-mathematicians. Finally, Pascal argues in terms of dispositio and economy. He claims that, unless you truly understand "the spirit of these rules," ${ }^{29}$ you will never be able to spell out the implications and consequences of a basic principle like "one must define everything and prove everything." ${ }^{30}$ This is a rebuttal to those who would claim that such a principle is nothing new. Pascal's reply is, if you think it's nothing new, then tell me exactly what it means.

As we have seen before, Pascal illustrates his discussion of the innovativeness of the treatise with a comparison between Descartes and Augustine that seeks to answer the question: did Descartes say something new when he wrote I think, therefore I am, since Augustine said the same thing twelve hundred years before? Here too, Pascal is following Montaigne, who asks the same question with regard to Philippe de Commynes and Tacitus:

When some years ago I read Philippe de Commines, certainly a very good author, I noted this remark as uncommon: That we must be very careful not to serve our master so well that we keep him from finding a fair reward for our service. I should have praised the idea [l'invention], not him; I came across it in Tacitus not long ago: Benefits are agreeable as long as they seem returnable; but if they go much beyond that, they are repaid with hatred instead of gratitude. And Seneca says vigorously: For he who thinks it is shameful not to repay does not want the man to live whom he ought to repay. Q. Cicero, in a weaker vein: He who thinks he cannot repay you can by no means be your friend. ${ }^{31}$

Montaigne describes himself as a once naïve reader who admired a particular thought in Commynes (that excessive devotion towards a superior generates ingratitude) and later found out that it was a topos that could be traced back to Cicero through Seneca and Tacitus. In this case the finding of the conférence is that Commynes did not say anything new. Commynes did not deserve the praise because the thought was not his own.

${ }^{29}$ De l'Esprit géométrique, p. 140.

${ }^{30}$ Ibid.

${ }^{31}$ Essays, III, 8, p. 718. 
To those familiar with Pascal's text this finding may sound somewhat disappointing because Pascal makes a more striking and counterintuitive point in Mathematical Mind. He argues that Descartes did say something new, even though it is true that Augustine said the same thing a long time before: "Far be it from me to say that Descartes is not the true author [of this principle], even if it were the case that he learned it by reading that great saint." ${ }^{\prime 32}$ According to Pascal, an equitable reader will acknowledge that in Descartes, I think, therefore I am is the first principle of an entire system of physics and metaphysics. If one examines the connections between the part and the whole, one will see that the cogito means immensely more in Descartes than it does in Augustine. But what about Montaigne's judgment of Commynes? The contrast with Pascal is remarkable. While Pascal's judgment of Descartes and Augustine comes across as bold and assertive, Montaigne presents himself as a cautious, even hesitant reader. He says he will defer to those more knowledgeable than he is to decide whether a particular thought is new or not:

We who have little contact with books are in this strait, that when we see some fine piece of inventiveness (quelque belle invention) in a new poet, some strong argument in a preacher, we dare not praise them for it until we have found out from some learned man whether this element is their own or someone else's. Until then I always stand on my guard. ${ }^{33}$

Determining whether Commynes said something new requires a good deal of erudition, which Montaigne does not claim to have. Or to put it more precisely, for Montaigne assessing the innovativeness of a text requires an excellent memory: one must know all the classics by heart. As every reader of Montaigne knows, the author of the Essays complains everywhere about his poor memory. It is very telling that after discussing the work of Tacitus at the end of the essay Montaigne qualifies his assessment in the following way: "This is what my memory of Tacitus offers me in gross, and rather uncertainly. All judgments in gross are loose and imperfect." ${ }^{34}$ In other words Montaigne is saying that his assessment of Tacitus should not be taken too seriously because assessing the value of a book requires an excellent memory, which he does not have. On the other hand neither erudition nor a good memory is necessary to determine if an interlocutor's idea is truly his own. Here, Montaigne shows neither caution nor hesitation. He challenges his interlocutor vigorously, or even better, he pretends like Socrates that he does not understand the idea his

${ }^{32}$ De l'Esprit géométrique, p. 141.

${ }^{33}$ Essays, III, 8, p. 718.

${ }^{34}$ Essays, III, 8, p. 721. 
interlocutor is putting forward: "We must either deliberately oppose it, or draw back under color of not understanding it, in order to feel out on all sides how it is lodged in its author." ${ }^{35}$ If in response to a direct challenge or to Socratic irony the interlocutor comes across as knowing what he his talking about, his idea is truly his own, and he deserves Montaigne's esteem. If not, he deserves contempt because he himself does not see the value of what he says. This is how Pascal summarizes Montaigne's art de conférer:

Those who say the same things do not all master [possèdent] them in the same way. This is why the incomparable author of $L$ 'Art de conférer devotes so much care to showing that we must not judge the capacity of a man according to the excellence of a clever remark we hear him make. Rather, instead of concluding that the person is admirable because the words are, let us inquire, Montaigne says, into the mind that produced them; let us find out whether it comes from memory, or from a happy coincidence; let us receive these words coldly and with scorn, in order to see if the person realizes that we do not value what he says as it should be valued. Most often, he will promptly retract himself; he will be driven away from that thought (which is better than he thinks it is) and will arrive at a new one that is trivial and laughable. It is therefore necessary to gauge how that thought resides in its author, how, through what means, and to what extent he masters it [il la possède]. ${ }^{36}$

Pascal's summary is perfectly exact and faithful, and in that sense Pascal does not say anything new when he borrows this entire passage from Montaigne. He innovates, however, in a subtle but decisive way. When Montaigne discusses l'art de conférer, he refers mainly to conversation between friends. The essay does discuss literary innovation. Yet when it comes to assessing the innovativeness of a text, Montaigne becomes hesitant and cautious. He defers to the erudite reader (the one with a perfect memory) who will determine if a certain idea has been used before. Pascal takes Montaigne's art de conférer and applies it fully and without reservations to textual analysis. In other words the technique described in Pascal's treatise is entirely borrowed from Montaigne, but in Pascal it applies to texts in addition to persons. What makes this move possible is that for Pascal, memory is irrelevant. It makes no difference if the cogito was in Augustine before it was in Descartes. It makes no difference if it was there verbatim or even if Descartes took it knowingly from Augustine instead of rediscovering it by chance. In making memory irrelevant, Pascal is still following Montaigne. As we have seen before, for Montaigne the fact that

${ }^{35}$ Essays, III, 8, p. 715.

${ }^{36}$ De l'Esprit géométrique, 140. 
a man has "a reputation for learning and a good memory" says little about the intrinsic qualities of his soul. ${ }^{37}$ Similarly, in his chapter on the education of children Montaigne says that a student may want to forget the source of the ideas he borrows from great writers in order to make them his own: "And let him boldly forget, if he wants, where he got them, but let him know how to make them his own." 38

In Montaigne these maxims apply to conversation and to pedagogy. Pascal extends their application from persons to texts and turns them into a hermeneutical principle. As far as textual analysis is concerned, Montaigne follows a traditional exegetical model: in order to find out if a particular thought is new, it is necessary to look at everything that has been written before. Pascal, on the other hand, follows a dialogical model: the "new" does not emerge in a comparison between one passage that was written recently and possible "sources" of this passage. The "new" is a quality that emerges when one considers the meaning of a book in its totality. This in turn, according to Pascal, points to the worth of a person, the author of the book. As we have seen before, the ultimate purpose of Montaigne's art de conférer is to test the worth of an interlocutor in a dialogue (and to exercise one's soul in the process). Pascal borrows this dialogical model and applies it to the interpretation of texts. I should add that for Pascal the "new" should never be seen as an intrinsic quality of a text. It emerges in a debate between two interpreters of the text: one who argues that the text does not say anything new and the other who argues the opposite. Determining the innovativeness of a text is an adversarial process.

Pascal concludes his discussion of Descartes and Augustine with a simile. The thought that Descartes borrowed from Augustine is like a splendid tree that grew in a field:

Whereas someone will say something by himself without comprehending the excellence of what he says, someone else will see a splendid sequence of consequences in it, so much so that I dare say those are no longer the same words; he is no more indebted to the one he learned it from than a splendid tree belongs to the one who tossed its seed, casually and unknowingly, in a deep soil that provided a fertile environment for growth.

The same thoughts sometimes grow very differently in someone other than their author: sterile in their native field, thriving when transplanted. ${ }^{39}$

${ }^{37}$ Essays, III, 8, p. 718.

${ }^{38}$ Essays, I, 26, p. 111.

${ }^{39}$ De l'Esprit géométrique, 142. 
According to the simile, the cogito in Augustine is nothing but a seed, and the splendid tree is Descartes's philosophical system. The fertility of the soil (i.e., the strength and beauty of Descartes's soul) has contributed to the beauty of the tree much more than the seed itself, which was planted there by chance. The final thought is that some seeds thrive by being transplanted. This thought is itself borrowed from Montaigne: “... and forms of speech, like plants, improve and grow stronger by being transplanted." ${ }^{\prime 4}$ The context of this quote is a discussion of the strengths and weaknesses of the French language, where Montaigne suggests that the French language could be enriched not through neologisms (which he dislikes) but by borrowing from technical languages like the language of war and hunting. Then comes the idea that words and expressions gain in strength when transplanted from one field to the next. In Montaigne the idea of transplanting is limited to the sphere of elocutio: words and expressions. When he transplants this thought into his own work, Pascal makes it grow to include not only elocutio but also inventio: the invention of the cogito cannot be claimed for Augustine. Even though the cogito came from Augustine originally, Descartes owns it because it grew and prospered in his soil.

Let us now see how Pascal deals with these hermeneutical issues in a somewhat more complex case, the Conversation with Monsieur de Sacy on Epictetus and Montaigne. This text purports to be the transcription of a conversation (a conférence, Montaigne would say) that took place between Pascal and his spiritual director, Monsieur de Sacy, at Port-Royal-des-Champs. It is impossible to know whether such a conversation actually took place. What we know is that most of the text is the transcription by Fontaine (Sacy's secretary) of a manuscript in which Pascal did a comparative assessment of the philosophy of Epictetus and the philosophy of Montaigne. The text presents the spiritual director as impressed by the strength of Pascal's mind but unimpressed by his doctrinal knowledge. According to Sacy, Pascal is brilliant in conversation, what he says is sound and true, but he does not say anything new:

He did feel that everything [Pascal] said was quite true. He enjoyed seeing the strength of his mind and of his words, but he did not see anything new in them. Everything great Monsieur Pascal told him he had already read in Saint Augustine. ${ }^{41}$

One could think of the entire conversation as Pascal's effort to persuade Sacy that he is saying something new. At the end, Sacy is at least half-persuaded, and

${ }^{40}$ Essais, III, 5, p. 665.

${ }^{41}$ Entretien avec M. de Sacy sur Epictète et Montaigne, in Les Provinciales, Pensées et opuscules, 717. 
he concedes to his interlocutor that he is "surprised to see how he managed to turn things to his advantage." ${ }^{42}$

How does Pascal do it? He follows the same hermeneutical principles we have discussed before. The main point of the comparison between Epictetus and Montaigne is to show that each of them is advocating principles that are true and valid and that each of them is also advocating principles that are false and dangerous. The more subtle point is that each author is an antidote for the errors of the other. The Stoic philosopher is right in saying that God is the highest good and that the first duty of human beings is to recognize the will of God and follow it. He errs in saying that human beings have in themselves the ability to do so. This is a manifestation of pride, a cardinal sin. Montaigne professes Skepticism. This is a sound doctrine because it shows the limits of human reason and it proves that knowledge of God must come through faith. On the other hand Skepticism makes Montaigne morally and intellectually lazy. From a Christian point of view, says Pascal, Stoics and Skeptics err because they do not see that there is a difference between the human condition after the Creation and the human condition after the Fall. Stoics describe human beings as if they were still in a pre-lapsarian state. Skeptics view human beings as if the Fall had left them with no remembrance of God whatsoever. Therefore, Pascal adds, one might establish a sound moral doctrine by putting Epictetus and Montaigne together: “... since one has the truth that offsets the error of the other, an alliance between them would result in a perfect moral doctrine." ${ }^{93}$ However, such an alliance is impossible:

But, instead of peace, their association would only lead to war and general destruction. Because one establishes certainty while the other establishes doubt, and one proves the greatness of man while the other proves his weakness, they destroy each other's truths and errors with equal effectiveness. ${ }^{44}$

Montaigne is an antidote for Epictetus's pride, but his Skepticism undermines the Stoic's rightful desire to know and obey God's will. Epictetus's desire to know and obey God's will is an antidote to Montaigne's laziness, but it excludes Montaigne's healthy questioning of the powers of human reason. It is therefore impossible to establish a coherent doctrine on the basis of an alliance between Stoicism and Skepticism. In Pascal's eyes this failure brings about a success because the mutually assured destruction of Stoicism and Skepticism makes room for the truth of the Gospel: "So much so that they can neither stand

${ }^{42}$ Entretien avec M. de Sacy, 737.

${ }^{43}$ Entretien avec M. de Sacy, 736.

${ }^{44}$ Ibid. 
alone because of their shortcomings nor unite because of their differences. Consequently, they collapse and disappear in order to give way to the truth of the Gospel." ${ }^{45}$ Only the Gospel, with its central figure of Christ as simultaneously divine and human, can teach human beings that they are both human and divine and therefore weak (like the Skeptics say) and great (like the Stoics say) at the same time. Only a superior form of equity, charity (i.e., the love of Christ), can accommodate the teachings of these two opposite schools of thought.

In conclusion, Pascal recommends reading Epictetus and Montaigne together as an intellectual and moral preparation for hearing the truth of Christianity:

This is why these readings must be done in a very careful way, with great restraint, and with full consideration of the social status and mores of the intended readers. I believe nonetheless that putting these readings together would have a good chance of success because one offsets the bad of the other. ${ }^{46}$

This recommendation follows the principle of decorum, because it points out that the method proposed here is not suited to everyone, and that the readings must be tailored to the particular circumstances of the reader. Even more importantly, the method itself is a form of oeconomica dispositio: it puts together two authors that are never read together, and it constitutes a complicated and circuitous path toward the truth of Christianity. At the end of the conversation Sacy and Pascal are in the same place, but the roads they took to get there are very different:

This is how these two great minds finally came to agreement regarding the reading of these philosophers, and both reached the same conclusion, even though they arrived at it in slightly different ways: Monsieur de Sacy came to it immediately, because of his clear grasp of the principles of Christianity; Monsieur Pascal arrived at it in a roundabout way, by following the principles of these two philosophers. ${ }^{47}$

As Kathy Eden points out, the root of the word oeconomia, oikos (the house), is clearly present in the mind of authors like Plutarch who liken the interpretation of literature to a long journey home. ${ }^{48}$ In his essay on how the young should read poetry (De audiendis poetis—Moralia 14D-37B) Plutarch presents the

\footnotetext{
${ }^{45}$ Entretien avec M. de Sacy, 736.

${ }^{46}$ Ibid., 738.

${ }^{47}$ Ibid., 739.

${ }^{48}$ See Hermeneutics and the Rhetorical Tradition, 30-36.
} 
study of literature as a propaedeutic to philosophy. Reaching philosophical wisdom is like coming home, but the path towards wisdom is straight only for those who are already wise. For everybody else coming home is an Odyssey: like Ulysses, the young student who wants to reach philosophical wisdom must travel through foreign lands and take the long way around before he comes home. A similar logic applies to Pascal's use of Epictetus and Montaigne. For Pascal wisdom is of course Christian wisdom. The path towards this wisdom is straight for Sacy, who is already a believer. For others whose faith may not be as strong as Sacy's, "a roundabout way" is the most economical one. Reading Epictetus and Montaigne, whose messages are in many ways foreign to Christianity, is paradoxically the best way of coming home to the Christian faith.

The richness of the connotations of oikos (the house) in oeconomia does not end here. As we have seen before in the rhetorical tradition and especially in Quintilian the economy of a text is the relationship between the parts and the whole. This notion is based on the image of the text as a social unit from which no one is excluded, in which every member is at home. ${ }^{49}$ In Quintilian's words the various parts of a speech should not clash (non pugnantia); they should not be like strangers (ignotae) but rather assembled by something like a social bond (aliqua societate). ${ }^{50}$ These metaphors resurface in Pascal's treatment of Epictetus and Montaigne. Here the image of the text as a social unit is a principle of interpretation, not composition, and Pascal is not reading a single text: he is reading two texts as if they were one. It is remarkable, however, that in keeping with the rhetorical tradition Pascal's metaphors are political throughout. He discusses the possibility of an "alliance" between Epictetus and Montaigne. He then warns that instead of "peace" the coming together of these two authors would result in "war and general destruction." 51 For anyone familiar with the rest of Pascal's work, this language brings up the imagery of civil war that is so important in the Pensées (and in seventeenth-century political thought in general). What Pascal is suggesting is that putting Epictetus and Montaigne together will result in civil war.

There is continuity, therefore, between this passage from the Conversation with Monsieur de Sacy, which deals with hermeneutics, and the famous fragment in the Pensées that discusses the relationship between justice and civil war. Pascal asks of his interlocutor, "What basis will he take for the economy of the world he wants to rule?" (60). He then adds that if human beings had any knowledge of true equity it would have imposed itself on all peoples: "True equity would have enthralled all the peoples of the world with its splendor." However, in the realm of politics, equity has been replaced by custom: "Custom is the whole of equity." This passage, like the texts we have seen before, is

\footnotetext{
${ }^{49}$ See Hermeneutics and the Rhetorical Tradition, 28-29.

${ }^{50}$ Quintilian, Institutio oratoria, 7.10.17.

${ }^{51}$ Entretien avec M. de Sacy, 736.
} 
about the relationship between economy and equity, but it casts doubt on the effectiveness of a hermeneutic approach to the law. Equity, as Aristotle understands it, consists in accommodating the generality of the law to the particular circumstances of the case. At the same time, judges who render equitable judgments deepen our understanding of the law because they clarify the connection between legal principles and their application. For Pascal, who follows Montaigne's Skeptical argument, trying to be equitable here would be catastrophic. Custom, by definition, does not stand on any principle: "Anyone who tries to bring it back to its first principle destroys it" (ibid.). One must accept what the law says without asking what it really means. If one inquires about the coherence of a legal system or its connection with legal principles, one opens up the door to infinite controversy. L'art de conférer does not apply here. "Saying something new" would mean looking into the principles that underlie the law ("return to the basic and primitive laws of the state which unjust custom has abolished"). This, Montaigne warns (and Pascal after him), leads to civil war.

In the light of what we have discussed, what do Pascal and Montaigne really mean when they talk about "saying something new"? Our modern notion of "new" does not apply here. We tend to think of it in terms of intellectual property law: I can claim an idea or an expression as my own if no one has claimed it before. Or we see it in terms of Romantic aesthetics: this book is new because it is the authentic expression of its author's radical singularity. For Montaigne and Pascal, in order to qualify as "new" an idea must meet two conditions: first, it must be true; second, it must be experienced as new.

Montaigne and Pascal do not see truth as a thing, an entity that exists out there. General knowledge is meaningless until it is particularized. A "truth" comes to life only when it has been internalized and appropriated. An idea is true, and it is our own only when it has become a part of who we are. That is because for Montaigne and Pascal a "truth" is first and foremost, a truth about ourselves. It is something about ourselves that was always there, undiscovered, and comes to light through reading or conversation. As Pascal puts it, "it is not in Montaigne but in myself that I find everything I see there" (689). In this fragment Pascal combines two Augustinian lines of thought. The first one, which comes via Montaigne, is the idea that truth cannot be owned privately and therefore belongs to everyone: "truth and reason are common to everyone, and no more belong to the man who first spoke them than to the man who says them later." 52 The second one is Augustine's reinterpretation of the Delphic formula,

${ }^{52}$ Essays, I, 26, p. 111. See Augustine, De libero arbitrio, 2.12.33, and Kathy Eden, Friends Hold All Things in Common, 132-34; also Seneca, Ad Lucilium Epistulae Morales, letter 12, tr. Richard M. Gummere (London, 1925), I, 73: “ 'Epicurus,' inquis, 'dixit. Quid tibi cum alieno?' Quod verum est, meum est." (“Epicurus," you reply, "uttered these words; what are you doing with another's property?" Any truth, I maintain, is my property.) 
know thyself: "Do not wander far and wide but return into yourself, it is in the inner person that truth dwells. ${ }^{" 53}$ Pascal follows Augustine in asserting that the most cogent truths are the truths about ourselves, because self-knowledge is the foundation of all knowledge. What Pascal brings to this Augustinian tradition is a vivid description of the experience of self-knowledge that takes place not only through introspection but also through reading or conversation: "When some passion or effect is described in a natural style, we find within ourselves the truth of what we hear, without knowing it was there. We are consequently inclined to like the person who made us feel it, for he has shown us not his wealth but our own ..." (652).

The epiphany that Pascal describes here does not happen very often, because it requires a specific kind of writing, the "natural style." In a fragment discussing those philosophers "who have dealt with self-knowledge," ${ }^{54}$ Pascal establishes a clear contrast between "Charron's depressing and tedious divisions" 55 and "Montaigne's muddle," composition. Authors who write like Montaigne are few and far between. Most authors are like Charron: they follow a straight, linear path; they are predictable; they do not surprise us. When we are lucky enough to find an author like Montaigne (who practices what the rhetorical tradition calls oeconomica dispositio), what we read comes across as new and different: "When we see a natural style we are quite amazed and delighted, because we expected to see an author and find a man ..." (675).

For Pascal, the "new" is the delightful surprise we experience when we learn something about ourselves in reading or conversation. This pertains to dispositio, as we have just seen. It also pertains to ethos: the experience of the "new" is possible only when the author of the book we read comes across as a fellow human being with whom we're having a free, open, and sincere conversation. ${ }^{57}$ If that kind of ethos is missing, the interlocutor comes across as a writer rather than a person. As Pascal puts it by quoting Petronius, "plus poetice quam humane locutus es" (you have spoken more as a poet than a man). ${ }^{58}$ This is why Pascal and Montaigne seek to identify in an interlocutor what is truly his own. It is only when we have grasped who the interlocutor really is that we can learn something about who we are, and what it is to be human. Classical moralists like Pascal are sometimes criticized for speaking in generalities about

${ }^{53}$ Augustine, De vera religione, 39.72: "Noli foras ire, in te ipsum redi; in interiore homine habitat veritas"; and see Pierre Hadot, Philosophy as a Way of Life, 65-67.

${ }^{54}$ Pensées, 780.

${ }^{55}$ Ibid. Cf. Pierre Charron's De la sagesse (Bordeaux, 1601).

${ }^{56}$ Ibid.

${ }^{57}$ See Marc Fumaroli, “Les Essais de Montaigne: 1'éloquence du for intérieur" in La Diplomatie de l'esprit (Paris, 1994), 125-61; also Quintilian, Institutio oratoria, 6.2.8-19.

${ }^{58}$ Pensées, 675. 
human beings, and for having an essentialist view of human nature ${ }^{59}$ It can be argued that the opposite is true: the main lesson of l'art de conférer is that an idea comes to life only when it has been appropriated and internalized by one person. If it sits out there, out of context, it may seem banal and empty. But its banality does not prevent it from being true or rather from becoming true when it is uttered by someone who really understands what it means. In Mathematical Mind after having vigorously argued that his ideas are new, Pascal concludes that instead of calling them "great, lofty, elevated, sublime," he would rather call them "lowly, common, familiar." ${ }^{60}$ For Pascal there is no contradiction between "saying something new" and saying something ordinary and familiar.

Columbia University.

${ }^{59}$ See Roland Barthes, "La Rochefoucauld: Réflexions ou Sentences et Maximes," in Le Degré zéro de l'écriture, suivi de Nouveaux essais critiques (Paris, 1972), 69-88.

${ }^{60}$ De l'Esprit géométrique, 145. 